\title{
Analysis of adenosine deaminase enzyme in HIV and Tuberculosis in Indian population
}

\author{
Shah R. P. ${ }^{1 *}$, Pawar G. B. ${ }^{2}$ and Bhiwgade D. A. ${ }^{1}$ \\ ${ }^{* 1}$ Department of Biotechnology and Bioinformatics, Padmashree Dr. D. Y. Patil University, Sector 15, CBD \\ Belapur, Navi Mumbai, 4000614 \\ ${ }^{2}$ S. I. E. S. College of Arts, Science and Commerce, Sion, Mumbai, 400022
}

\begin{abstract}
Adenosine deaminase is a catabolic enzyme, part of the purine salvage metabolic pathway. The principal function of ADA nevertheless appears to be related to the development of immune system and cell differentiation in human. Tuberculosis is an ancient disease of man and is still of the most widespread. Case rates are varied markedly according to age, sex, race and geographic locations. The global incidence of tuberculosis (TB) has sharply increased particularly in areas where HIV and tuberculosis are both prevalent. The Adenosine deaminase activity was found to be elevated in the fluid sample of most of the suspected cases of Tuberculosis and HIV. But it has been observed that though the patients presented typical clinical picture of tuberculosis infection and HIV, the adenosine deaminase activity is much above the reference range. Estimation of the various fractions of protein of the patient with high Adenosine Deaminase activity in the fluid showed increase in albumin, alpha -1, alpha- 2, beta and gamma globulin while protein electrophoresis of the serum of the same patient showed a decrease in the albumin and increase in the alpha - 1, alpha - 2, beta and gamma globulin. The Adenosine deaminase activity along with the lymphocyte to neutrophil ratio, total leucocyte count and protein electrophoresis can be used as a diagnostic test for the diagnosis of HIV and HIV plus tuberculosis infection.
\end{abstract}

\section{Introduction}

Worldwide the HIV epidemic has resulted in an increase in the number of cases of tuberculosis in both developed and developing countries, with sub-Saharan Africa being most affected. ${ }^{2}$ In Africa, HIV infection is widespread and the majority of the population have been infected with tuberculosis by early childhood. In these circumstances there will be large number of HIV and tuberculosis co-infected individuals 8 . The Co infected persons have anannual risk ofreactivational tuberculosis of approximately 5 $10 \%$, in contrast to the estimated $10 \%$ life-time risk of reactivation in an HIV negative individuals. The possibility of HIV infection in cases of tuberculosis and Vice-Versa, should be considered at all times. Therefore the picture of HIV-associated tuberculosis in Africa is dominated by large number of patients with reactivational disease. This is supported by DNA finger printing techniques, which have not yet been widely applied in Africa. In India, $56 \%$ of AIDS patients have been reported to be suffering from tuberculosis [1]. It has been seen that AIDS with a co-infection of tuberculosis exist more predominantly in the lower economic group of people. Here again it is observed that pulmonary tuberculosis is more commonly seen as a coinfection in AIDS patients. There are a few number of test available for the diagnosis of tuberculosis, such as Adenosine deaminase activity, polymerase chain reaction, Interferon gamma and Lysozyme. There are also microbiological confirmation of the microorganisms i.e. culturing of the fluid obtained, looking out for the Acid fact bacilli in the sputum or fluid. The various tests for the diagnosis of tuberculosis are Polymerase Chain Reaction
(PCR), is expensive and is not found to be more sensitive to pleural fluid. Lysozyme concentration greater than $15 \mathrm{mg} / \mathrm{dl}$ and Gamma interferon concentration above $140 \mathrm{pg} / \mathrm{ml}$ is sensitive. Thus the only test left is Adenosine deaminase Activity (ADA). This is a single test which is sensitive and specific and at the same time inexpensive and easy to perform [2]. Adenosine deaminase is the best test for early TB detection where TB is endemic or other diagnostic means are expensive. Adenosine deaminase analysis is a simple and inexpensive colorimetric test that can be performed ob body fluids. Since 1978, ADA it has been used in the diagnosis of tuberculous effusion by Puras, et al 1978; Ocana, et al 1993; Petterson, 1984; Fontana, et al 1988 [3-6]. The ADA measurement is used commonly is European and Asian countries where these is a higher incidence of tuberculosis. ADA is also being considered as a diagnostic tool for HIV [7]. Adenosine deaminase is a catabolic enzyme, part of the purine salvage metabolic pathway [810]. The principal function of the enzyme appears to be related to the development of the immunesystem and cell differentiation in humans [11]. Increased Adenosine deaminase activity in body fluids is classically associated with tuberculosis. Mycobacterium tuberculosis is not the source of Adenosine deaminase activity. However increased Adenosine deaminase activity in biological fluids from tuberculosis and HIV positive patients might be due to the interaction of the mycobacterium and HIV with the host factors [12-14]. 


\section{Materials and Methods \\ Collection of samples}

Blood samples were collected by venepunctured method in EDTA vacutainers and were analyzed for Total Leukocyte count, Differential count and Erythrocyte Sedimentation rate(ESR). The blood samples collected in plain tube without any anticoagulant was centrifuged. The supernatant collected (Serum) was subjected to Protein Electrophoresis TB IgG, TB IgM and Adenosine deaminase activity.

Blood samples were collected from all the subjects with 10-12 hrs of fasting in the morning in EDTA vacutainer and in plain vacutainer. The bloods from the EDTA vacutainer were subjected to Total Leukocyte count, Differential count and ESR. The blood from the plain vacutainer was allowed to clot and the serum was collected from it by centrifuging at $1600 \mathrm{rpm}$. The serum was estimated for total protein concentration and subjected to protein electrophoresis and other clinical parameters. Such as HIV, ADA level and TB IgG (TGB) and TB IgM (TGM).

Chemicals: Phosphate Buffer,Buffered Adenosine,Ammonium Sulphate Stock Solution,Phenol Nitropruside Solution,Alkaline Hypochlorite Solution,SPE gel,Barbital Buffer,20\%Aceticacid-30\%Methanol

Solution,Ponceau Stain,Leishman Stain,EDTA bulbs,Pathozyme Kit.All the chemicals were purchased from local dealers.

Estimation of adenosine deaminase activity Adenosine deaminase activity was estimated by GIUSTI Method.

Protein electrophoresis on agarose gel by beckman coulter electrophoresis system

The protein electrophoresis is done by serum protein (SPE) electrophoresis Kit by Paragon (Beckman Coulter). Blood samples were collected in the manner normally used for any laboratory test. Freshly drawn serum from a fasting individual is preferred, but samples stored at $2 \mathrm{C}$ to $8 \mathrm{C}$ for up to 72 hours may also be used.

The total protein of the sample determination Prepare all samples as instructed in specimen preparation. Fill each compartment of paragon electrophoresis cell with $45 \mathrm{ml}$ of B-2 Barbital Buffer. Remove SPE Gel from foil package and place on a paper towel. Blot gently with Gel Blotter. Discard Blotter. Align Template with "A" position dots located on edged of Gel. Apply Template to Gel such that Template Slots contact Gel surface first. Gently rub finger across Template to ensure seal. Apply 5 microlitre of sample across each template slot. Allow 5 minutes for diffusion after last sample has been applied. Then gently blot Template with Template
Blotter.Discard Blotter and Template. Place Gel onto Gel Bridge Assembly, aligning positive (+) and negative ( -- ) sides of Gel with corresponding positions marked on Gel Bridge Assembly. Place Assembly into paragon Electrophoresis cell and cover cell. Insert paragon electrophoresis cell power supply. Set voltage to 100 volts, turn on power, and electrophoresis for 25 minutes.Upon completion of electrophoresis, remove Gel from paragon Electrophoresis cell, and place into Gel Frame. Place the Gel into Acid - Alcohol solution I for 3 minutes. Remove Gel from Acid- Alcohol solution I. Wipe excess solution from back of Gel and place in Paragon Dryer until completely dry. When the Gel is completely dried, place the it in the ponceau stain for 3 minutes and after that into the Acetic Acid solution for 3 minutes. Remove Gel from Acetic - Acid solution and from the frame. Blot Gel with Gel blotter and place in paragon Dryer until completely dry. Do not place Gel back into the Gel frame. Evaluate Gel by scanning with Beckman Coulter densitometer at $600 \mathrm{~nm}$.

\section{Result and Discussion}

The Adenosine deaminase activity was found to be elevated in the blood samples of most of the suspected cases of Tuberculosis and HIV. It has been observed that though the patients presented typical clinical picture of tuberculosis infection and HIV, the Adenosine deaminase activity is much above the reference range. Estimation of the various fractions of protein of the patient with high Adenosine deaminase activity in the blood showed decrease in albumin, alpha-1, alpha-2, beta and gamma globulins In HIV positive patients, the ADA values have been found to be more than $50 \mathrm{U} / \mathrm{L}$. In normal subjects Serum protein levels were within normal range while in HIV with TB ( -ve ) and TB $(+v e)$ serum proteins levels were found to be marginally lower than the normal subjects ( Figure -1). In normal subjects Serum Albumin levels were within the normal range, while in HIV with TB (-ve) and Tb (+ve) serum Albumin level were found to be marginally lower than the normal subjects (Figure-2). The serum globulin was found to be reduced in normal subjects as compared to higher in HIV with TB (-ve) and TB (+ve) subjects (Figure-3). Alpha 1 globulin levels in normal patients were within the normal range, while in HIV with TB (-ve) alpha 1 globulin levels were marginally increased and in the HIV with TB $(+v e)$ the same levels were nearly doubled as compared to HIV with TB (-ve) (Figure-4). The level of Alpha 2 globulin also showed progressively increased within normal range for normal patient, marginally increase for HIV with TB (-ve) and substantially increased for HIV with TB (+ve) patients (Figure- 5). The Beta globulin levels in normal subjects were within normal 
range. However, the HIV with TB (+ve) patients showed marginally increased and significant increased in HIV with Tb (-ve) patients (Figure6 ). The Gamma globulin levels were found to be within the normal range for normal subjects, while the same was found to be increased marginally in HIV with TB (+ve) patients and substantially increased in HIV with TB (+ve) patients (Figure 7). The ESR showed normal trend in normal patients whereas the same increased more than two fold in HIV with TB (-ve) patients and more than three fold in HIV with TB (+ve) Patients (Figure - 8). The Leucocyte count (Total WBC Count) was normal for normal subjects, marginally increased for HIV with TB (-ve) patients while it increased substantially for HIV with TB (+ve) patients (Figure - 9). The Neutrophil count was within the normal range for normal subjects, slightly elevated for HIV with TB (-ve) patients and drastically reduced to nearly $50 \%$ in HIV with TB (+ve) patients (Figure - 10). The Lymphocyte count was within the normal range for the normal subjects slightly decreased for HIV with TB (-ve) patients and significantly increased for the HIV with TB (+ve) patients (Figure - 11). The Eosinophil count was found to be within the normal range for normal subjects, marginally decreased for HIV with TB (-ve) patients and significantly increased for the HIV with TB (+ve) patients (Figure - 12). The monocyte count was normal for the normal subjects, marginally increased for HIV with TB (ve) patients and nearly doubled for HIV with TB (+ve) patients (Figure- 13). The TB IgG levels showed normal value for the normal subjects, it decreased slightly for HIV with TB (-ve) patients and more than doubled for HIV with TB (+ve) patients (Figure- 14). The TB IgM levels were normal for normal subjects, slightly decreased for HIV with TB (-ve) patients and substantially increased by more than three times for HIV with TB (+ve) patients (Figure- 15). ADA level was normal for normal subjects, increased nearly four times for HIV with TB (-ve) patients and increased nearly seven times for HIV with TB (+ve) patients (Figure - 16). In Descriptive Statistics, all clinical parameters found to be significantly elevated in Group 2 and Group 3 when compared with Group 1. However Basophile contents were found to play no significant role in all the three groups. In Regression Analysis, ADA level was taken as a dependent variable and other clinical parameters as independent variables. The Multiple Regression Model yielded the adjusted value of $\mathrm{R}^{2}$ as 0.743 ; which indicates that the explanatory power of the model is $74.30 \%$ which is statistically quite significant. $R^{2}=0.743$ indicates that nearly $74 \%$ variations in ADA level are explained by the linear multiple regression model. In the Test for normality by Shapiro-Wilk's test, the Null Hypothesis (Ho) is accepted. Ho validates that the residuals follow normal distribution at $p$-value $>0.05$. It means the random errors in statistical analysis amount only up to $5 \%$; while the standard statistical analysis of the data collected indicates 95\% confidence level for accuracy. The present investigation proposes that Adenosine deaminase activity along with the lymphocyte to neutrophil ratio; total leucocyte count and protein electrophoresis can be used as a diagnostic test for the diagnosis of HIV and HIV plus tuberculosis infection.

\section{Conclusion}

Since $p$-value $>0.05$, the normality assumption of random errors is not rejected. It means that the data collected for the present study are normally distributed and therefore the estimations of statistical parameters by various techniques are unbiased and reliable.

\section{Reference}

[1] Sengupta D., Singh V. D., Sathpaty S. K. (1997) A study of 3200 cases. Family medicine Indi 1 : 14 -17.

[2] Valdes L., San Jose, Alvarez D., et al., (1993) Chest,103 : 458- 465.

[3] Puras M. A., Gakis C., Budron M., Androni G. (1978) Br. Med J. 2, 1751-52.

[4] Ocana I., Matinez Vasquez J. M., Segura R. M., Fernandez - De - Devilla T., Capdevila J. (1993) Chest 84, 51-53.

[5] Petterson T., Ojala K., Weber T. H. (1984) Acts Med scand., 251, 299-304.

[6] Fontan J., Verea H., Perez J., et al. (1988) Chest , 93, 303--307.

[7] Roth B. J. (1999) Chest, 116, 3-5.

[8] Nolan L. L., Kidder G. W. (1980) Antimicrobe Agents. Chem - other, 17, 567.

[9] Durak I., Beduk Y., Kavuteu M., Suzer O., Yamam O., Ozturk H. S., Canbolate O., Ulutepe S. (1997) Cancer Invest, 15, 212.

[10] Gheraldi A., Sarcoron M. E., Petavy A. F., Peyron F.(1995) Life Sci ., 65, 1733.

[11] Moriwaki Y., Yamamoto T., Higashino K. Histopathology 199, 14, 1321.

[12] Banales L. J., Rivera - Martinez E., Perez Gonzales L., Sclman M., Raymond Y., Nava A. (1999) Arch Med Res., 3015, $358-359$.

[13] De Cock K. M., Grant A., Poter J. D. H. (1995) Lancet, 345, 833-836.

[14] Brien R. J., Perriens J. H. (1995) AIDS, 9, 665-673. 
Table 1-Descriptive Statistics: The Table of Summary Statistics (Mean, S.D. \& Significant Groups) for all the variables is as follows:

\begin{tabular}{|c|c|c|c|c|c|}
\hline $\begin{array}{l}\text { SR. } \\
\text { NO. }\end{array}$ & $\begin{array}{ll}\text { PA } & \text { RA } \\
\text { METERS } & \end{array}$ & $\begin{array}{l}(1) \\
\text { NORMAL } \\
\text { (MEAN } \pm \text { S.D.) }\end{array}$ & $\begin{array}{l}(2) \\
\text { HIV WITH TB } \\
\text { NEGATIVE } \\
\text { (MEAN } \pm \text { S.D.) }\end{array}$ & $\begin{array}{l}\text { (3) } \\
\text { HIV WITH TB } \\
\text { POSITIVE } \\
\text { (MEAN } \pm \text { S.D.) }\end{array}$ & $\begin{array}{l}\text { SIGNIFICANT } \\
\text { GROUPS }\end{array}$ \\
\hline 1 & Age & $43.23 \pm 15.59$ & $38.34 \pm 10.46$ & $41.73 \pm 12.72$ & - \\
\hline 3 & $\begin{array}{ll}\text { Total } & \text { Serum } \\
\text { Protein } & \end{array}$ & $6.75 \pm 0.41$ & $6.64 \pm 0.55$ & $6.49 \pm 0.57$ & $(1) \&(3),(2) \&(3)$ \\
\hline 3 & $\begin{array}{l}\text { Total Serum } \\
\text { Albumin }\end{array}$ & $4.06 \pm 0.55$ & $3.30 \pm 0.46$ & $3.22 \pm 0.53$ & (1) \& (2), (1) \& (3) \\
\hline 4 & Serum Globulin & $2.67 \pm 0.53$ & $3.35 \pm 0.51$ & $3.27 \pm 0.60$ & (1) \& (2), (1) \& (3) \\
\hline 5 & $\begin{array}{l}\text { Albumin Globulin } \\
\text { Ratio }\end{array}$ & $1.63 \pm 0.66$ & $1.01 \pm 0.25$ & $1.03 \pm 0.34$ & (1) \& (2), (1) \& (3) \\
\hline 6 & Alpha 1 Globulin & $0.26 \pm 0.06$ & $0.30 \pm 0.29$ & $0.60 \pm 0.23$ & (1) \& (3), (2) \& (3) \\
\hline 7 & Alpha 2 Globulin & $0.68 \pm 0.16$ & $0.78 \pm 0.12$ & $1.10 \pm 0.17$ & $\begin{array}{l}\text { (1) \& (2), (1) \& (3) } \\
\text { (2) \& (3) }\end{array}$ \\
\hline 8 & Beta Globulin & $0.78 \pm 0.13$ & $0.91 \pm 0.18$ & $0.81 \pm 0.21$ & (1) \& (3), (2) \& (3) \\
\hline 9 & Gamma Globulin & $1.05 \pm 0.24$ & $1.63 \pm 0.37$ & $1.38 \pm 0.00$ & $\begin{array}{l}\text { (1) \& (2), (1) \& (3) } \\
\text { (2) \& (3) }\end{array}$ \\
\hline 10 & ESR & $22.08 \pm 15.06$ & $53.64 \pm 24.65$ & $66.76 \pm 29.22$ & $\begin{array}{l}\text { (1) \& (2), (1) \& (3) } \\
\text { (2) \& (3) }\end{array}$ \\
\hline 11 & Neutrophiles & $60.03 \pm 8.79$ & $65.52 \pm 13.08$ & $39.39 \pm 16.62$ & $\begin{array}{l}\text { (1) \& (2), (1) \& (3) } \\
\text { (2) \& (3) }\end{array}$ \\
\hline 12 & Lymphocytes & $37.26 \pm 8.49$ & $32.54 \pm 12.46$ & $57.17 \pm 15.77$ & $\begin{array}{l}\text { (1) \& (2), (1) \& (3) } \\
\text { (2) \& (3) }\end{array}$ \\
\hline 13 & Eosinophiles & $3.02 \pm 1.74$ & $2.30 \pm 1.20$ & $3.56 \pm 2.79$ & $(1) \&(2),(2) \&(3)$ \\
\hline 14 & Basophiles & 0 & 0 & 0 & 0 \\
\hline 15 & Monocytes & $1.74 \pm 0.74$ & $1.87 \pm 0.82$ & $3.16 \pm 1.59$ & (1) \& (3), (2) \& (3) \\
\hline 16 & WBC Count & $7319 \pm 1760.45$ & $9388 \pm 3615.76$ & $\begin{array}{l}10316.83 \\
5882.15\end{array}$ & (1) \& (2), (1) \& (3) \\
\hline 17 & TGB & $93.86 \pm 17.73$ & $80.17 \pm 19.71$ & $207.32 \pm 53.77$ & $\begin{array}{l}\text { (1) \& (2), (1) \& (3) } \\
\text { (2) \& (3) }\end{array}$ \\
\hline 18 & TGM & $0.54 \pm 0.17$ & $0.53 \pm 1.82$ & $1.58 \pm 0.47$ & (1) \& (3), (2) \& (3) \\
\hline 19 & ADA Level & $11.82 \pm 5.84$ & $42.88 \pm 6.83$ & $74.36 \pm 6.94$ & $\begin{array}{l}\text { (1) \& (2), (1) \& (3) } \\
(2) \&(3)\end{array}$ \\
\hline
\end{tabular}

\section{Regression Analysis:}

Dependent Variable : ADA level

Independent variables : Total Serum Albumin,

Alpha 1 Globulin, Alpha 2 Globulin,

Beta Globulin, Gamma Globulin, ESR

Lymphocytes, WBC Count, TGB, TGM

\begin{tabular}{l|l|l|l|l|}
\multicolumn{1}{|c}{ Table 2-Model Summary } \\
Model & $\mathrm{R}$ & $\mathrm{R}$ Square & $\begin{array}{l}\text { Adjusted } \\
\text { R Square }\end{array}$ & $\begin{array}{l}\text { Std. Error of } \\
\text { the Estimate }\end{array}$ \\
\hline 1 & $.862^{\mathrm{a}}$ & .743 & .738 & 12.4707 \\
\hline
\end{tabular}


a. Predictors : (Constant), WBC_THOU, L diff count, BETA, GAMMA, TGM, ESR, ALBUMIN, ALPHA1, ALPHA2, TGB

\begin{tabular}{|c|c|c|c|c|c|c|c|}
\hline \multirow{3}{*}{ Model } & \multirow{2}{*}{\multicolumn{2}{|c|}{$\begin{array}{l}\text { Unstandardized } \\
\text { Coefficients }\end{array}$}} & \multirow{2}{*}{$\begin{array}{l}\text { Standardized } \\
\text { Coefficients }\end{array}$} & \multirow[b]{3}{*}{$\mathrm{T}$} & \multirow[b]{3}{*}{ Sig. } & \multirow{2}{*}{\multicolumn{2}{|c|}{ Collinearity Statistics }} \\
\hline & & & & & & & \\
\hline & B & Std. Error & Beta & & & Tolerance & VIF \\
\hline 1 (Constant) & -12.677 & 6.606 & & -1.919 & .056 & & \\
\hline ALPHA 1 & 9.206 & 2.339 & .107 & 3.936 & .000 & .710 & 1.409 \\
\hline ALPHA 2 & 25.949 & 3.370 & .249 & 7.699 & .000 & .503 & 1.990 \\
\hline BETA & 8.340 & 3.030 & .066 & 2.752 & .006 & .910 & 1.099 \\
\hline GAMMA & 10.115 & 1.659 & .152 & 6.095 & .000 & 847 & 1.181 \\
\hline ESR & .160 & .021 & .197 & 7.655 & .000 & .796 & 1.256 \\
\hline TGB & .110 & .012 & .319 & 9.380 & .000 & .454 & 2.203 \\
\hline TGM & 1.021 & .465 & .154 & 2.194 & .029 & .857 & 1.167 \\
\hline ALBUMIN & -6.112 & 1.068 & -.148 & -5.721 & .000 & .786 & 1.273 \\
\hline L diff count & .184 & .040 & .132 & 4.544 & .000 & .623 & 1.606 \\
\hline WBC_THOU & .279 & .128 & .052 & 2.186 & .029 & .921 & 1.086 \\
\hline
\end{tabular}

a. Dependent Variable : ADA level

R-squared value of 0.743 indicated $74 \%$ of variation in ADA Level is explained by linear model

Test for Normality: Normality Assumption for Residual validated using Shapiro - Wilk's Test Hypothesis: $\mathrm{H}^{0}$ : Residuals follow Normal Distribution v/s $\mathrm{H}^{1}$ : not $\mathrm{H}_{0}$

Table 4-Tests of Normality

\begin{tabular}{|l|l|l|l|l|l|l|}
\hline \multirow{2}{*}{} & \multicolumn{4}{|l|}{ Kolmogorov - Smirnova } & \multicolumn{3}{l|}{ Shapiro-Wilk } \\
\cline { 2 - 7 } & Statistic & df & Sig. & Statistic & df & Sig. \\
\hline Unstandardized Residual & .027 & 499 & $-200^{\star}$ & .997 & 499 & $.591^{\text {a }}$ \\
\hline
\end{tabular}

* This is a lower bound of the true significance.

a. Lilliefors Significance Correction 
$(g \%)$

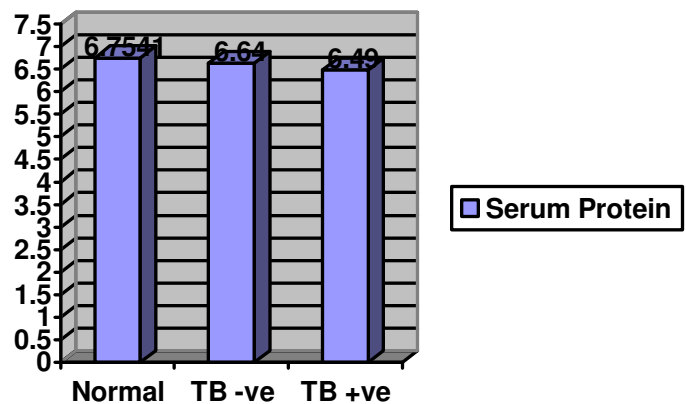

$\mathrm{N}=$ normal ssubjects

TB - ve $=$ HIV with TB - ve subjects

$\mathrm{TB}+\mathrm{ve}=\mathrm{HIV}$ with TB +ve subjects

Fig. 1- Serum Protein

(g\%)

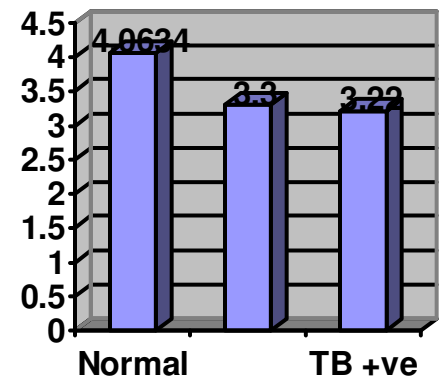

Fig. 2- Serum Albumin

$(9 \%)$

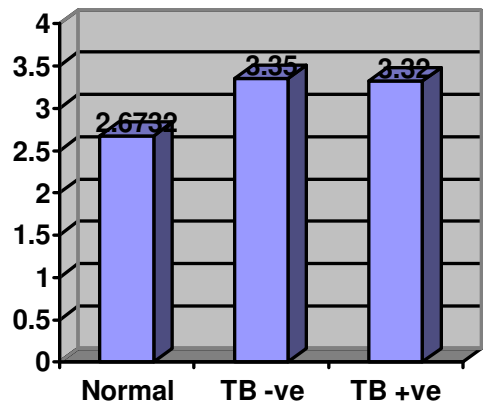

Fig. 3- Serum Globulin

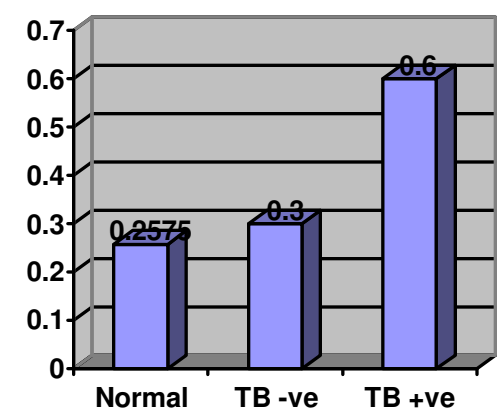

(g\%)

Globulin

Fig. 4- Alpha 1 Globulin 
(g\%)

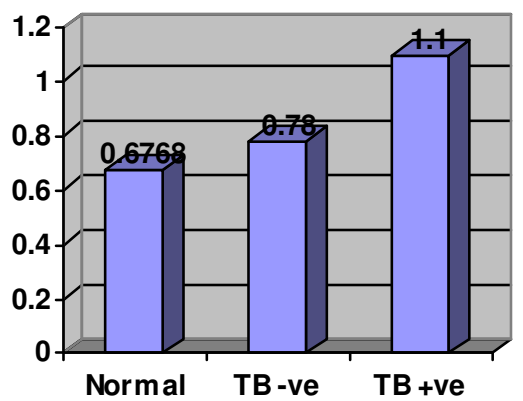

$\mathrm{N}=$ normal ssubjects

TB $-\mathrm{ve}=$ HIV with TB - ve subjects

$\mathrm{TB}+\mathrm{ve}=\mathrm{HIV}$ with TB +ve subjects

\section{$\square$ Alpha 2}

Globulin

Fig. 5- Alpha 2 Globulin

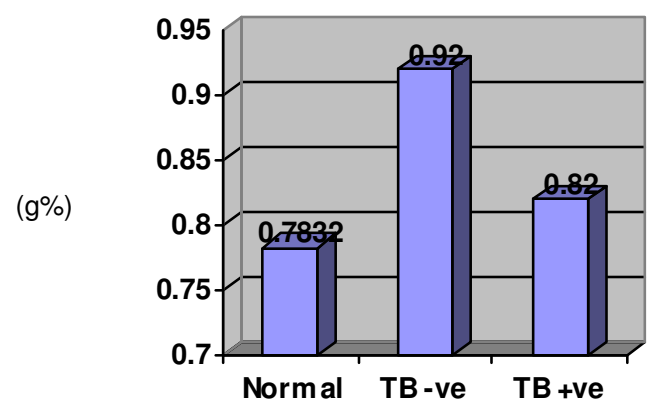

Fig. 6- Beta Globulin

$(g \%)$

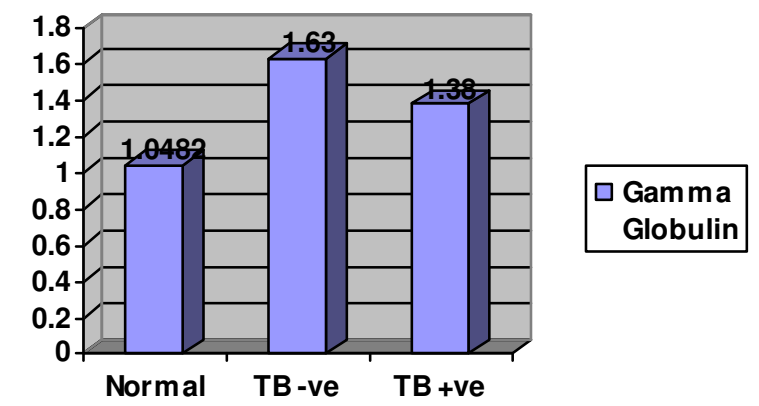

Fig. 7- Gamma Globulin

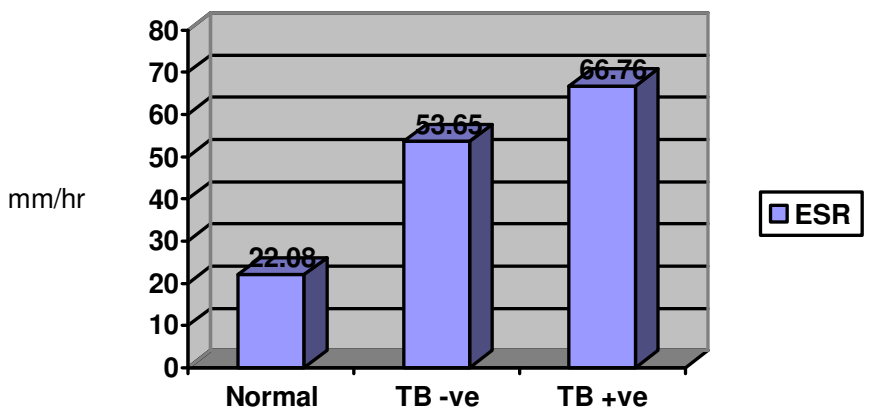

Fig. 8- ESR 


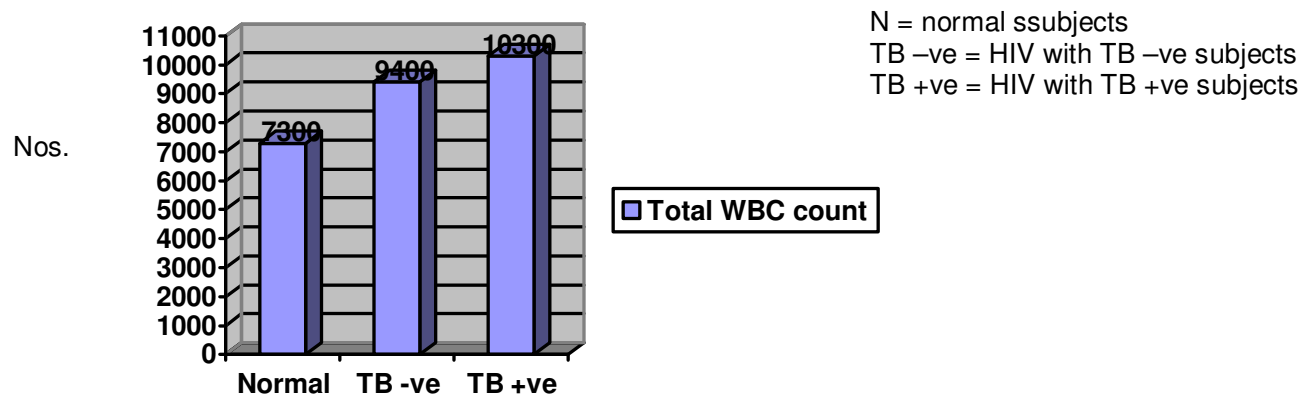

Fig. 9- Total WBC count

(\%)

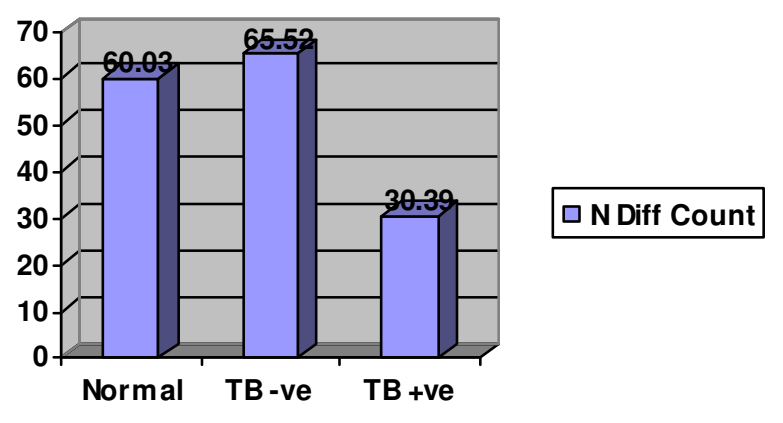

Fig. 10- N Diff Count ( Neutrophil )

(\%)

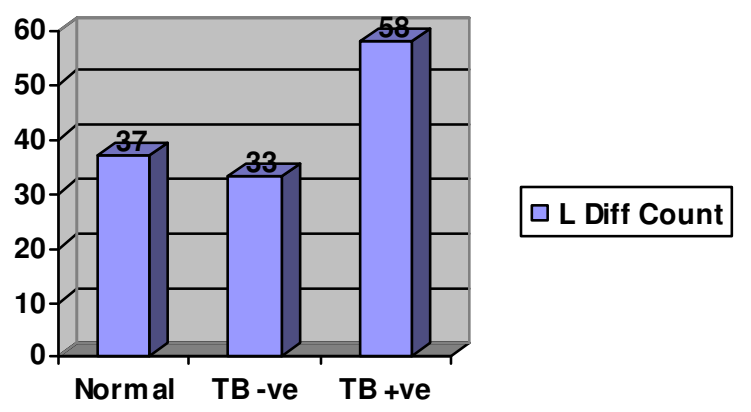

Fig. 11- L Diff Count ( Lymphocyte )

(\%)

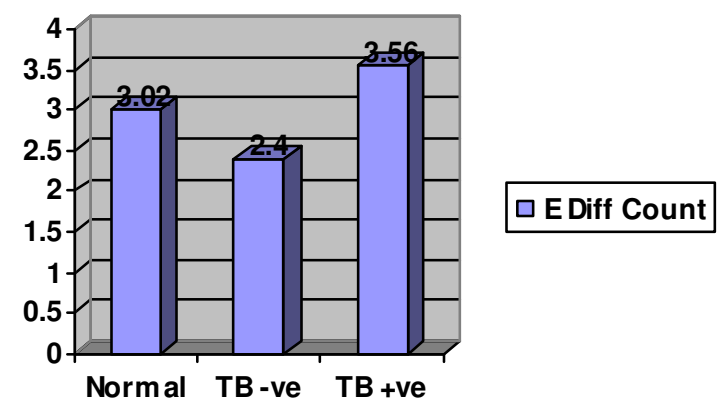

Fig. 12- E Diff Count ( Eosinophil ) 
(\%)

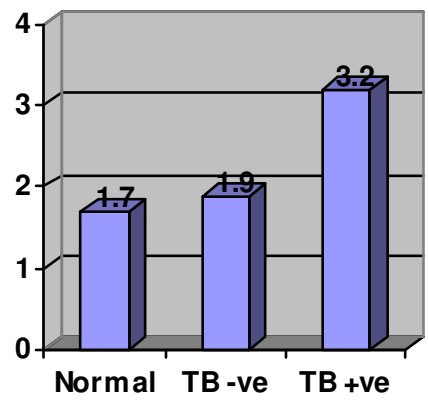

$\mathrm{N}=$ normal ssubjects

TB - ve $=$ HIV with TB - ve subjects

$\mathrm{TB}+\mathrm{ve}=\mathrm{HIV}$ with $\mathrm{TB}+\mathrm{ve}$ subjects

Fig. 13- M Diff Count ( Monocyte )

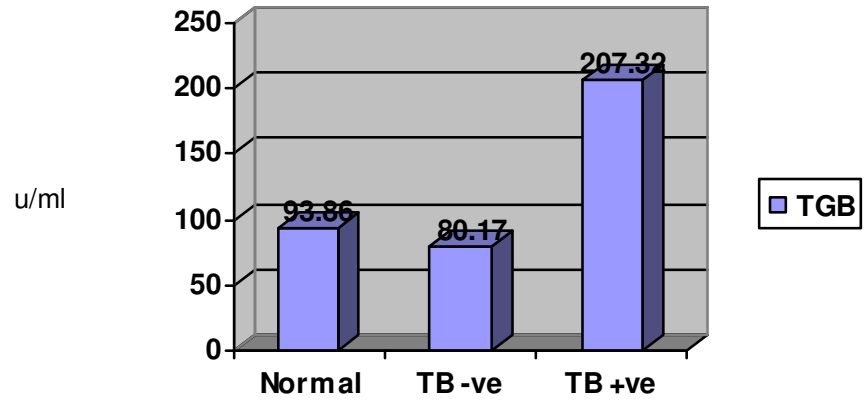

Fig. 14- TGB

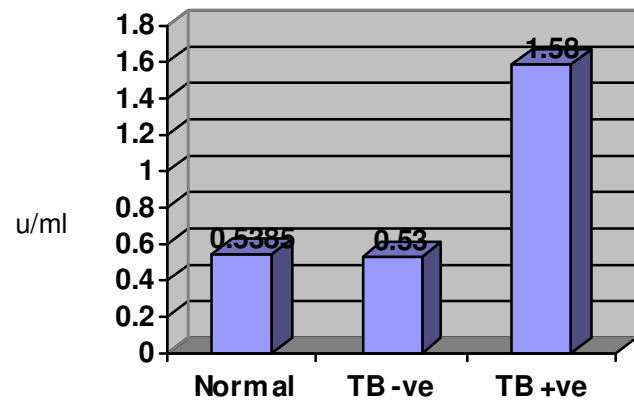

口 TGM

Fig. 15- TGM

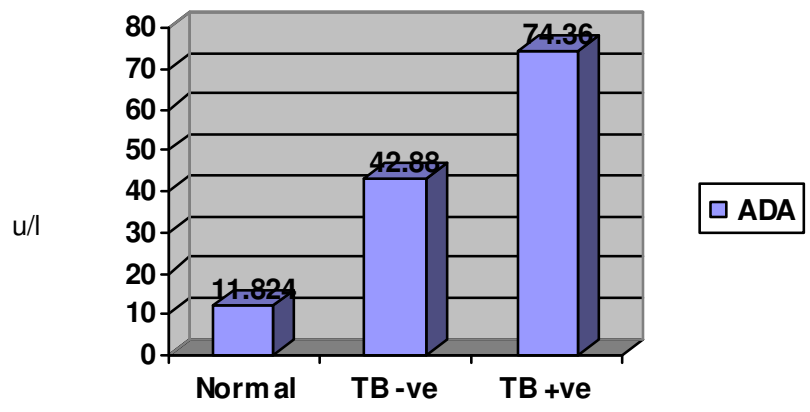

Fig. 16- ADA Level 